\title{
Protective Effect of Sodium Selenite on Genotoxicity to Human Whole Blood Cultures Induced by Aflatoxin $B_{1}$
}

\author{
Fatime Geyikoğlu* and Hasan Türkez \\ Department of Biology; Faculty of Arts and Sciences; Atatürk University; fgeyik@atauni.edu.tr; 25240; Erzurum - \\ Turkey
}

\begin{abstract}
The aim of this study was to investigate the effects of selenium and aflatoxin on human whole blood cultures (WBC) in relation to induction of sister-chromatid exchange (SCE). Results showed that the frequency of SCEs in peripheral lymphocytes was significantly increased by the direct-acting mutagen $A F B_{1}$ (at doses 5 and $10 \mu M$ except for $1 \mu \mathrm{M})$ compared with controls. When sodium selenite $\left(\mathrm{Na}_{2} \mathrm{SeO}_{3}\right)$ was added at a molar ratio of $5 \times 10^{-7}$ and $1 \times 10^{-6}$, cells did not show significant increase in SCE frequency. Whereas, SCE rates induced by the various $A F B_{1}$ concentrations could be significantly reduced by the presence of $\mathrm{Na}_{2} \mathrm{SeO}_{3}$ in a clear dose-related manner. These results indicated that selenite and $A F B_{1}$ mutually antagonized their ability to cause DNA damage leading to the formation of SCEs. However, selenium didn't completely inhibit induction of SCES by AFB ${ }_{1}$ compared with controls. $A F B_{1}$ induced oxidative damage contributed to its genotoxicity in human WBC.
\end{abstract}

Key words: Aflatoxin $\mathrm{B}_{1}$, Selenium, Sister-chromatid exchanges, Genotoxicity, Blood

\section{INTRODUCTION}

Dietary selenium is an essential trace element in human nutrition (Shi et al., 1995). Sodium selenite is an anticarcinogenic/ antimutagenic agent that exhibits carcinogenic/mutagenic properties in some short-term test systems used for the detection of DNA-damaging agents. One such test system is sister-chromatid exchange (SCE) induction (Ray, 1984). SCEs were significantly potentiated by the presence of $\mathrm{Na}_{2} \mathrm{SeO}_{3}$ (Lin and Tseng, 1992). From the viewpoint of genotoxicity, selenium has not been adequatly studied (Cemeli et al., 2003). In contrast, $\mathrm{AFB}_{1}$, human carcinogen and the most potent genotoxic agent, is mutagenic in many model systems and produces chromosomal aberrations, micronuclei, sister-chromatid exchange, unscheduled DNA synthesis, and chromosomal strand breaks as well as forms adducts in rodent and human cells ( $\mathrm{Jia}$ and Groopman, 1999). Selenium has been shown in animal studies to inhibit aflatoxin hepatocarcinogenesis (Shi et al., 1995). These inhibitory effects are supported by many diverse mechanisms, including inhibition of carcinogen formation, modulation of carcinogen metabolism, inhibition of mutagenesis and genotoxicity, inhibition of cell proliferation (Lu et al., 1996).

It is important to verify lack of toxicity of selenium on different systems and to investigate mechanisms of its action throughout the whole processes of mutagenesis. The mutagenicity of $\mathrm{AFB}_{1}$ has been demonstrated using many model systems including HeLa cells, Bacillus subtilis, Neurospora crossa, Salmonella typhimurium, and Chinese hamster ovary (CHO) cells (Wang and

\footnotetext{
* Author for correspondence
} 
Groopman, 1999). However, no study has been carried out to evaluate the genotoxicity of selenium with $\mathrm{AFB}_{1}$ on blood cultures. The objective of this work was to investigate sodium selenite and its interaction with $\mathrm{AFB}_{1}$ in the SCE test using human whole-blood cultures. Because the ability of selenium to minimize genetic effects on different tissues may have potential for designing strategies to reduce the carcinogenic influence of $\mathrm{AFB}_{1}$.

\section{MATERIAL AND METHOD}

Human peripheral blood lymphocyte cultures were set up according to a slight modification of the protocol described by Evans and O'Riordan (1975). Whole heparinized blood from four healthy non-smoking donors between age 25 and 28 with no history of exposure to any genotoxic agent were used. Questionnaires were obtained for each blood donor to evaluate exposure history and informed consent forms were signed by each donor. For all the volunteers hematological and biochemical parameters were analysed and disease was not detected.

The heparinized blood $0.5 \mathrm{ml}$ was cultured in $5 \mathrm{ml}$ of culture medium (Chromosome Medium B, Biochrom, Leonorenstr. 2-6.D-12247, Berlin) with $5 \mu \mathrm{g} / \mathrm{ml}$ of phytohemagglutinin (Biochrom). $\mathrm{AFB}_{1}$ $\left(\mathrm{C}_{17} \mathrm{H}_{12} \mathrm{O}_{6}\right.$, Sigma Chemical Co., St. Louis, MO. USA) (in concentrations of 1,5 and $10 \mu \mathrm{M}$ ) and sodium selenite $\left(\mathrm{Na}_{2} \mathrm{SeO}_{3}\right.$, Sigma, St. Louis) (in concentrations of $5 \times 10^{-7}$ and $1 \times 10^{-6} \mathrm{M}$ ) added to the cultures just before incubation. To each individual, lymphocyte culture without $\mathrm{AFB}_{1}$ and $\mathrm{Na}_{2} \mathrm{SeO}_{3}$ were studied as a control group. The experiments were performed on 12 groups as follows:

\section{Group 1: Control}

Group 2: Sodium selenite $\left(5 \times 10^{-7} \mathrm{M}\right)$ alone.

Group 3:Sodium selenite $\left(1 \times 10^{-6} \mathrm{M}\right)$ alone.

Group 4:AFB $1(1 \mu \mathrm{M})$ alone.

Group 5:AFB $1(5 \mu \mathrm{M})$ alone.

Group 6:AFB ${ }_{1}(10 \mu \mathrm{M})$ alone.

Group 7:AFB $1(1 \mu \mathrm{M})+\mathrm{Na}_{2} \mathrm{SeO}_{3}\left(5 \times 10^{-7} \mathrm{M}\right)$.

Group 8: $\mathrm{AFB}_{1}(5 \mu \mathrm{M})+\mathrm{Na}_{2} \mathrm{SeO}_{3}\left(5 \times 10^{-7} \mathrm{M}\right)$.

Group 9: $\mathrm{AFB}_{1}(10 \mu \mathrm{M})+\mathrm{Na}_{2} \mathrm{SeO}_{3}\left(5 \times 10^{-7} \mathrm{M}\right)$.

Group 10:AFB $1(1 \mu \mathrm{M})+\mathrm{Na}_{2} \mathrm{SeO}_{3}\left(1 \times 10^{-6} \mathrm{M}\right)$.

Group 11:AFB $1(5 \mu \mathrm{M})+\mathrm{Na}_{2} \mathrm{SeO}_{3}\left(1 \times 10^{-6} \mathrm{M}\right)$.

Group 12: $\mathrm{AFB}_{1}(10 \mu \mathrm{M})+\mathrm{Na}_{2} \mathrm{SeO}_{3}\left(1 \times 10^{-6} \mathrm{M}\right)$.
Groups of 7-12 represented simultaneous treatment of $\mathrm{AFB}_{1}$ and $\mathrm{Na}_{2} \mathrm{SeO}_{3}$. With the aim of providing successive visualization of SCEs, 5bromo-2'-deoxyuridine (Sigma, St. Louis, final concentration $20 \mu \mathrm{M}$ ) was added after culture initation. The cultures were incubated in complete darkness for $72 \mathrm{~h}$ at $37^{\circ} \mathrm{C}$. Exactly $70 \mathrm{~h}$ and $30 \mathrm{~min}$ after begining of incubations, colcemid (Sigma, St. Louis) was added to the cultures to achieve a final concentration of $0.5 \mu \mathrm{g} / \mathrm{L}$. After hypotonic treatment $(0.075 \mathrm{M} \mathrm{KCl})$ followed by three repetitive cycles of fixation in methanol/acetic acid solution $(3: 1, \quad \mathrm{v} / \mathrm{v})$, centrifugation, and resuspension, the cell suspension was dropped onto chilled, grease-free microscopic slides, airdried, aged, and then differentially stained for the inspection of SCE rate according to fluorescence plus Giemsa (FPG) procedure (Perry and Wolff, 1974). For each treatment condition, well-spread second division metaphases containing 42-46 chromosomes in each cell were scored, and the values obtained were calculated as SCEs per cell.

\section{Statistical analyses}

Experimental data were analyzed using one-way analysis of variance (ANOVA) to determine whether any treatment significantly differed from controls and/or each other. Significant differences between the controls and/or treated samples were confirmed by Fisher's least significant difference (LSD) test.

\section{RESULTS}

The effects on the number of SCEs of $\mathrm{AFB}_{1}$ and $\mathrm{Na}_{2} \mathrm{SeO}_{3}$ in human WBC are shown in Table 1.

Sodium selenite alone in concentrations $5 \times 10^{-7}$ and $1 \times 10^{-6} \mathrm{M}$ did not significantly affect SCE rates in human lymphocytes. In contrast increasing concentrations of $\mathrm{AFB}_{1}(5$ and $10 \mu \mathrm{M})$ elevated the frequencies of SCEs in these cells compared with controls. No significant increase in SCE frequency was observed at the lowest $\mathrm{AFB}_{1}$ dose $(1 \mu \mathrm{M})$. $\mathrm{Na}_{2} \mathrm{SeO}_{3}$ significantly reduced the number of $\mathrm{AFB}_{1}$-induced SCEs. A dose-dependent decrease in SCEs was demonstrated with inhibition observed at selenium concentrations of $5 \times 10^{-7} \mathrm{M}$ or higher (Table 1, Figs. 1 and 2). However, the rates of SCEs following selenium treatment were significantly high in comparison with control values. 
Table 1 - The effects on the number of SCEs of $\mathrm{AFB}_{1}$ and $\mathrm{Na}_{2} \mathrm{SeO}_{3}$ in human WBC.

\begin{tabular}{|c|c|c|c|}
\hline Culture types & $\begin{array}{c}\text { Number of } \\
\text { samples }\end{array}$ & $\begin{array}{l}\text { Range of } \\
\text { SCEs }\end{array}$ & SCEs/cell \\
\hline $\mathrm{Control}^{+}$ & 4 & $0-8$ & $6.10 \pm 0.28^{\mathrm{a}}$ \\
\hline $\mathrm{SS}\left(\mathrm{D}_{1}\right)$ & 4 & $2-9$ & $6.27 \pm 0.31^{\mathrm{a}}$ \\
\hline $\mathrm{SS}\left(\mathrm{D}_{2}\right)$ & 4 & $2-10$ & $6.35 \pm 0.42^{\mathrm{a}}$ \\
\hline $\mathrm{AFB}_{1}(1 \mu \mathrm{M})$ & 4 & $3-11$ & $6.49 \pm 0.55^{\mathrm{a}}$ \\
\hline $\mathrm{AFB}_{1}(5 \mu \mathrm{M})$ & 4 & $4-19$ & $11.20 \pm 0.63^{b}$ \\
\hline $\mathrm{AFB}_{1}(10 \mu \mathrm{M})$ & 4 & $3-28$ & $16.18 \pm 0.87^{\mathrm{c}}$ \\
\hline $\mathrm{AFB}_{1}(1 \mu \mathrm{M})+\mathrm{SS}\left(\mathrm{D}_{1}\right)$ & 4 & $3-10$ & $6.17 \pm 0.21^{\mathrm{a}}$ \\
\hline $\mathrm{AFB}_{1}(5 \mu \mathrm{M})+\mathrm{SS}\left(\mathrm{D}_{1}\right)$ & 4 & $3-17$ & $9.47 \pm 0.55^{\mathrm{d}}$ \\
\hline $\mathrm{AFB}_{1}(10 \mu \mathrm{M})+\mathrm{SS}\left(\mathrm{D}_{1}\right)$ & 4 & $3-22$ & $12.44 \pm 0.62^{\mathrm{e}}$ \\
\hline $\mathrm{AFB}_{1}(1 \mu \mathrm{M})+\mathrm{SS}\left(\mathrm{D}_{2}\right)$ & 4 & $1-9$ & $6.38 \pm 0.53^{\mathrm{a}}$ \\
\hline $\mathrm{AFB}_{1}(5 \mu \mathrm{M})+\mathrm{SS}\left(\mathrm{D}_{2}\right)$ & 4 & $3-16$ & $8.66 \pm 0.45^{\mathrm{f}}$ \\
\hline $\mathrm{AFB}_{1}(10 \mu \mathrm{M})+\mathrm{SS}\left(\mathrm{D}_{2}\right)$ & 4 & $4-21$ & $11.46 \pm 0.80^{b}$ \\
\hline
\end{tabular}

+ Without aflatoxin $\mathrm{B}_{1}$ and sodium selenite. $\mathrm{SS}=$ =sodium selenite. +SS $\left(\mathrm{D}_{1}\right)=$ sodium selenite treated culture with low concentration. $+\mathrm{SS}\left(\mathrm{D}_{2}\right)=$ sodium selenite treated culture with high concentration. Values are mean \pm SD. Means in the same column followed by the same letter are not significantly different at the $\mathrm{p}<0.05$ level.

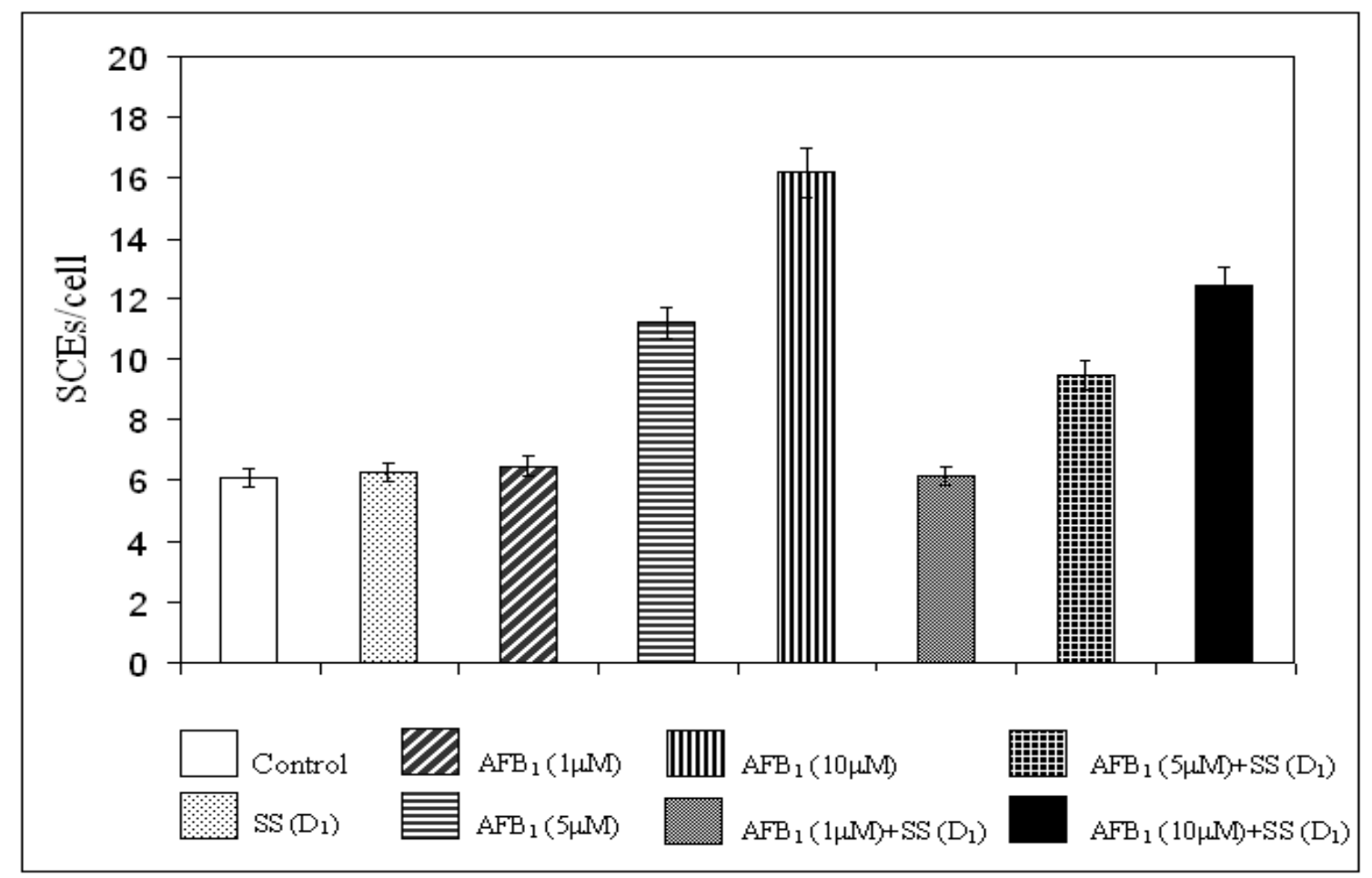

Figure 1 - The effects of sodium selenite $\left(5 \times 10^{-7} \mathrm{M}\right)$ on SCE frequency in peripheral lymphocytes induced by $\mathrm{AFB}_{1}$. 


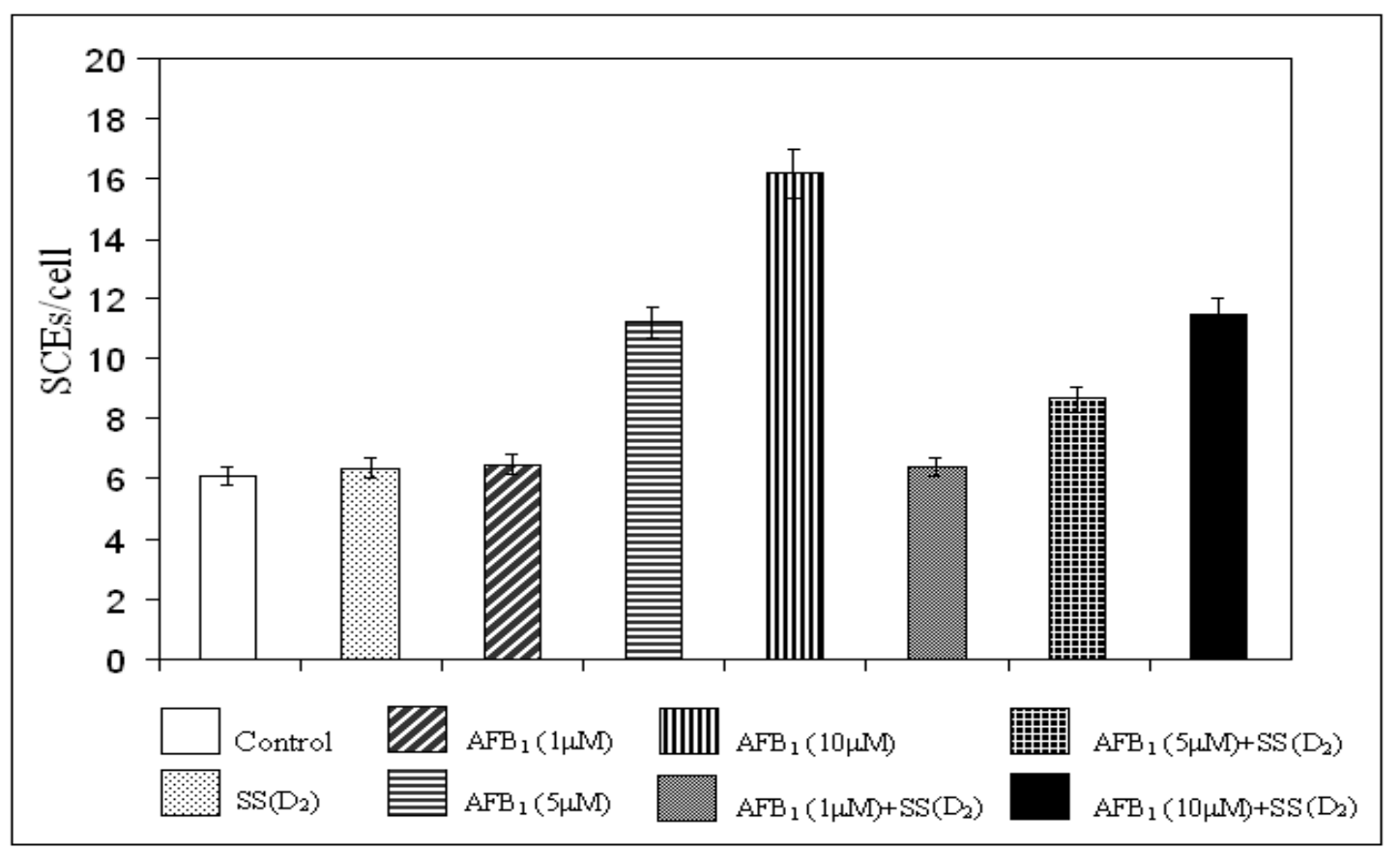

Figure 2 - The effects of sodium selenite $\left(1 \times 10^{-6} \mathrm{M}\right)$ on SCE frequency in peripheral lymphocytes induced by $\mathrm{AFB}_{1}$.

\section{DISCUSSION}

The normal human leukocytes stimulated to produce toxic oxygen metabolites cause sister chromatid exchanges in cultured mammalian cells (Weitzman and Stossel, 1981; Weitberg et al., 1983). Recent studies have shown that aflatoxin $B_{1}$ enhances reactive oxygen species formation and causes oxidative damage (Chan et al., 2003). Also, $\mathrm{AFB}_{1}$ plays a primary role in the generation of $\mathrm{AFB}_{1}$-mediated genetic damage (Wang and Groopman, 1999). The present study suggested, but did not prove that aflatoxin $\mathrm{B}_{1}(5$ and $10 \mu \mathrm{M})$ reacted with components of human WBC, resulting in the formation of toxic intermediate compounds. Some of the oxygen products could cause SCE formation in peripheral lymphocytes. In a previous study, oxidative damage, including formation of 8-oxodeoxyguanosine (8-oxodG), was observed in rat hepatic DNA following exposure to $\mathrm{AFB}_{1}$ (Wang and Groopman, 1999). In our study, SCEs were increased in cells treated with $\mathrm{AFB}_{1}$ alone (except for $1 \mu \mathrm{M}$ ) and this effect was highly magnified with $\mathrm{AFB}_{1}$ dosage. A timeand dose dependent increase in hepatic levels of 8oxodG residues in liver DNA treated with $\mathrm{AFB}_{1}$ has been recently reported (Shen et al., 1995; Yaborough et al., 1996).
The risk for $\mathrm{AFB}_{1}$ hepatocarcinogenesis could be modified in animals by using a number of chemoprotective agents (Wang and Groopman, 1999). It was strinking that a dramatic reduction of $\mathrm{AFB}_{1}$-induced SCEs in peripheral lymphocytes by the increase in the amount of $\mathrm{Na}_{2} \mathrm{SeO}_{3}$ was demonstrated by our study. These data suggested that selenium could be affecting as an antioxidant. Because, selenium is a prosthetic group essential for the catalytic activity of glutathione peroxidase (GSHpx) (Chow, 1979). The selenium-dependent glutathione peroxidase could detoxify both hydrogen peroxide and lipid hydroperoxides (Leopold, 1976; Sandstrom and Marklund, 1990). $\mathrm{AFB}_{1}$-induced reactive oxygen species formation and lipid peroxidation (LPO) might play a role in its cytotoxicity (Chan et al., 2003). $\mathrm{AFB}_{1}$-induced LPO was also found in hepatocytes (Liu et al., 1999). In the present study, erythrocytes were present in the incubation medium. Glutathione peroxidase activities increased significantly in erythrocytes from mice supplemented with selenium dietary (Arai et al., 2002). Erythrocytes are known to have GSHpx and glutathione-Stransferase (GST) (Ozturk and Gumuslu, 2004). On the other hand, glutathione is a major componenet of RBCs (Ray, 1984) that plays a central role in the antioxidant defenses of cells 
(Meister, 1983). It is a cofactor of the enzyme glutathione peroxidase (Leopold, 1976). Again, glutathione conjugates with $\mathrm{AFB}_{1}$ (Madle et al., 1986). Thus, it could be possible that $\mathrm{AFB}_{1^{-}}$ induced oxidative damage acted as an intermediate for the genetic damage observed. However, a mechanism consisting of glutathione-Se-reactive oxygen species formation from $\mathrm{Na}_{2} \mathrm{SeO}_{3}$ and $\mathrm{AFB}_{1}$ involving the participation of glutathione in $\mathrm{RBCs}$ might play a key role in this antagonism between $\mathrm{AFB}_{1}$ and selenium. Also, it is predicted that the induction of detoxification enzymes (GSHpx and GST) following exposure to aflatoxin might contribute to the reduction in covalent binding of $\mathrm{AFB}_{1}$ to macromolecules as reported in liver (Loury and Hsieh, 1984). Covalent binding of $\mathrm{AFB}_{1}$ to adenosine (Andrea and Haseltine, 1978), cytosine (Yu et al., 1991) and guanine in DNA in vitro has been reported (Wang and Groopman, 1999). In cultured $\mathrm{CHO}$ cells selenium treatment did not affect $\mathrm{AFB}_{1}$-DNA binding (Shi et al., 1995). Whereas, Chen et al. (1982), found that covalent binding of $\mathrm{AFB}_{1}$ to liver DNA and RNA was higher in chicks fed the selenium-deficient diets than the chicks supplemented with selenium or vitamin E or both (Shamberger, 1985).

Despite the uncertainity about the specific role of selenium in human WBC, the SCE test showed that sodium selenite was non-genotoxic, while $\mathrm{AFB}_{1}$ induced DNA damage. It was also shown that sodium selenite decreased the genotoxicity of $\mathrm{AFB}_{1}$ when administered at the same time in a clear dose-related manner. This is the first report describing the protective effects of Se against $\mathrm{AFB}_{1}$ genotoxicity on human WBC. It could be possible that $\mathrm{AFB}_{1}$-induced reactive oxygen species formation and oxidative damage might also contribute to its genotoxicity. The protective effect could be an important cytogenetic characteristic of sodium selenite, yet how this activity relates to the antimutagenic property of this agent is difficult to understand. Results also showed that selenium did not completely inhibit induction of SCEs by $\mathrm{AFB}_{1}$. As a matter of fact, the rates of SCEs following selenium treatment were still higher than controlled values observed in the present study.

\section{REFERENCES}

Andrea, A. D. D. and Haseltine, W. A. (1978), Modification of DNA by aflatoxin $\mathrm{B}_{1}$ creates alkalilabile lesions in DNA at positions of guanine and adenine. Proc Natl Acad Sci USA., 75, 4120-4124.

Arai, T.; Magori, E. and Morimoto, Y. (2002), Changes in activities of enzymes in erythrocytes from ddY mice supplemented with dietary selenium. Exp Anim., 51, 517-519.

Cemeli, E.; Carder, J.; Anderson, D.; Guillamet, E.; Morillas, M. J.; Creus, A. and Marcos, R. (2003), Antigenotoxic properties of selenium compounds on potassium dichromate and hydrogen peroxide. Teratog Carcinog Mutagen., 2, 53-67.

Chan, H. T.; Chan, C. and Ho, J. W. (2003), Inhibition of glycyrrhizic acid on aflatoxin B1-induced cyotoxicity in hepatoma cells. Toxicol., 188, 211-217.

Chen, J.; Goetchius, M. P.; Combs, G. F. and Campbell, T. L. (1982), Effects of diatery selenium and vitamin $\mathrm{E}$ on covalent binding on aflatoxin to chick liver cell macromolecules. J. Nutr., 112, 350-355.

Chow, C. K. (1979), Nutritional influence on cellular antioxidant defense systems. Am J Clin Nutr., 32, 1066-1081.

Evans, H. J. and O'Riordan, M. L. (1975), Human peripheral blood lymphocytes for the analysis of chromosome aberrations in mutagen tests. Mutat Res., 31, 135-148.

Leopold, F. (1976), Glutathione peroxidase brought in to focus. In: Pryor, W. A. (Ed.). Free Radicals in Biology. New York: Academic Press. v. 5. pp. 223-254.

Lin, J. K. and Tseng, S. F. (1992), Chromosomal aberrations and sister-chromatid exchange induced by $\mathrm{N}$-nitroso-2-acetylaminofluorene and their modifications by arsenite and selenite in Chinese hamster ovary cells. Mutat Res., 265, 203-210.

Liu, J.; Yang, C. F.; Lee, B. L.; Shen, H. M.; Ang, S. G. and Ong, C. N. (1999), Effect of Salvia miltiorrhiza on aflatoxin B1-induced oxidative stress in cultured rat hepatocytes. Free Radic Res., 31, 559-568.

Loury, D. N. and Hsieh, D. P. (1984), Effects of chronic exposure to aflatoxin B1 and aflatoxin M1 on the in vivo covalent binding of aflatoxin B1 to hepatic macromolecules. J. Toxicol. Environ. Health, 13, 575-587.

Lu, J.; Pei, H.; Ip, C.; Lisk, D. J.; Ganther, H. and Thompson, H. J. (1996), Effect on an aqueous extract of selenium-enriched garlic on in vitro markers and in vivo efficacy in cancer prevention. Carcinog., 17, 1903-1907.

Madle, E.; Korte, A. and Beek, B. (1986), Species differences in mutagenicity testing: I. Micronucleus and SCE tests in rats, mice, and Chinese hamsters with aflatoxin B1. Teratog Carcinog Mutagen., 6, 1-13.

Meister, A. (1983), Selective modification of glutathione metabolism. Science (Wash. DC)., 220, 472-477. 
Ozturk, O. and Gumuslu, S. (2004), Age-related changes of antioxidant enzyme activities, glutathione status and lipid peroxidation in rat erythrocytes after heat stress. Life Sci., 75, 1551-1565.

Perry, P. and Wolff, S. (1974), New Giemsa method for the differential staining of sister chromatids. Nature, 251, 156-158.

Ray, J. H. (1984), Sister-chromatid exchange induction by sodium selenite: reduced glutathione converts $\mathrm{Na}_{2} \mathrm{SeO}_{3}$ to its SCE-inducing form. Mutat Res., 141, 49-53.

Sandstrom, B. E. and Marklund, S. L. (1990), Effects of variation in glutathione peroxidase activity on DNA damage and cell survival in human cells exposed to hydrogen peroxide and t-butyl hydroperoxide. Biochem J., 271, 17-23.

Shamberger, R. J. (1985), The genotoxicity of selenium. Mutat Res., 154, 29-48.

Shen, H. M.; Ong, C. N.; Lee, B. L. and Shi, C. Y. (1995), Aflatoxin $B_{1}$-induced 8-hydroxydeoxyguanosine formation in rat hepatic DNA. Carcinog., 16, 419-422.

Shi, C. Y.; Hew, Y. H. and Ong, C. N. (1995), Inhibition of aflatoxin B1-induced cell injury by selenium: an in vitro study. Hum Exp Toxicol., 14, 55-60.
Wang, J. S. and Groopman, J. D. (1999), DNA damage by mycotoxins. Mutat Res., 424, 167-181.

Weitberg, A. B.; Weitzman, S. A.; Destrempes, M.; Latt, S. A. and Stossel, T. P. (1983), Stimulated human phagocytes produce cytogenetic changes in cultured mammalian cells. N. Engl. J. Med., 308, 26-29.

Weitzman, S. A. and Stossel, T. P. (1981), Mutation caused by human phagocytes. Science (Wash. DC)., 212, 546-547.

Yaborough, A.; Zhang, Y. J.; Hsu, T. M. and Santella, R. M. (1996), Immunoperoxidase detection of hydroxydeoxyguanosine in aflatoxin $\mathrm{B}_{1}$-treated rat liver and human oral mucosal cells. Cancer Res., 56, 683-688.

Yu, F. L.; Huang, X.; Bender, W.; Wu, Z. and Chang, J. C. S. (1991), Evidence for the covalent binding of aflatoxin $\mathrm{B}_{1}$-dichloride to cytosine in DNA. Carcinog., 12, 997-1002. 